\title{
Mental Models of School for Preschool Children
}

\author{
A. Oğuzhan Kıldan ${ }^{1}$, Mehmet Altan Kurnaz ${ }^{2 *}$, Berat Ahi ${ }^{3}$ \\ ${ }^{1}$ Faculty of Education, University of Kastamonu, Kastamonu 37200, Turkey. \\ ${ }^{2}$ Faculty of Education, University of Kastamonu, Kastamonu 37200, Turkey. \\ *E-mail:makurnaz@kastamonu.edu.tr,altan.kurnaz@gmail.com \\ ${ }^{3}$ Faculty of Education, University of Kastamonu, Kastamonu 37200, Turkey.
}

\begin{abstract}
The aim of this study was to determine mental models of 334 pre-school children concerning school. Children in the city center of Kastamonu in the Western Black Sea region of Turkey were included. Content analysis was conducted on pictures drawn by the children, and the models were split into two groups, scientific and nonscientific. The scientific group was split into three types; the nonscientific group, into four. About $40 \%$ of the children had a scientificbased school perception, while $60 \%$ were nonscientific. No significant difference was found between the mental models of females and males. Few studies have investigated mental models, so this study fills a gap, but further studies would aid the understanding of the relevant pedagogic architecture.
\end{abstract}

Key Words: mental model, pre-school child, drawing picture, school

\section{Introduction}

A school is a structure where education is provided, made meaningful by the people in it. Schools are devoted to teaching and learning, but they are also where social needs are met (Hoy \& Miskel, 2005). Durkheim (1972) defines school as the place where social identity is established, while Weber (1964) describes it as a place providing skills to prepare individuals for social roles. Because of these essential functions, it is important to understand how individuals benefiting from educational services perceive schools (Yıldiz, 2012). The literature contains many studies concerning how schools are perceived (Aksoy \& Baran, 2010; Saban, 2008; Y1ldı, 2012). In the study conducted by Saban (2008), students were asked to produce metaphors about school. It was concluded that students define school as "the place of love and solidarity," "the place of knowledge and learning," and "the beautiful place to be happy." Yildiz (2012) made elementary school students draw pictures to determine their perceptions: they generally drew their class, teacher, or garden. On the other hand, in Aksoy and Baran's (2010) study on perceptions of children aged 60-72 months, children drew their own pictures while playing.

A well-designed school creates an environment of trust, which contributes positively to studentteacher relations (Gislason, 2010) and improves socialization, fostering friendship, cooperation, solidarity, and personhood (Brown, 2012; Gislason, 2009). In addition, schools must be places where children are entertained. In the research of Rieh, Kim, and Yu (2011) and Aksoy and Baran (2010), entertain- 
ment ranked very highly by children when assessing the school environment. In their designed school model, Owens and Valesky (as cited in Gislason, 2009) placed emphasis on ecological features. Especially for kindergarten students, there must be imaginative places in beautiful, green areas (Gür \& Zorlu, 2002). While open areas provide a sense of solidarity, they can harm to the child in terms of having a special area in the school (Leiringer \& Cardellino, 2011). Not only does a well-designed environment attract and motivate a child, it can also affect the attitude of the child towards teachers and friends. In addition, the physical environment has an impact on success, concentration, and even the health of those within the school (Duran-Narucki, 2008; Gislason, 2009; Green \& Turrell, 2004; Kumar, O'Malley, \& Johnston, 2008; Tanner, 2000; Woolner, 2011).

Transportation facilities and the land on which the school is established are another factor. The land should be complementary to the serviced environment, and the school should be 200-400 meters from students' homes so they can walk (Uysal, 2006). Hence, the participation of local people is increased, coherent settlements are created, children become more interested in their physical environments, and the development of environmental consciousness is improved (Rahaim \& Moore, 1982, as cited in Uysal, 2006). As school transportation is increasingly carried out by private cars and service vehicles, costs increase and children lead less active lives, worrying education officers and health officers (Hine, 2009). In a Canadian study, students walking or riding bicycles to class generally reported lower BMIs and weights with more stable blood sugar levels (Larouche, Lloyd, Knight, \& Tremblay, 2011). Walking in early childhood prevents obesity and cardiovascular diseases in advanced ages (Larouche et al., 2011; Wong, Faulkner, Buliung, \& Irving, 2011). The ability to get to school without a vehicle promotes health and helps the child appreciate the environment, gain self-confidence, and acquire cognitive skills such as inversion.

\section{Mental Models}

The simplification of a system of interrelated objects or constructs and the structure of that system is a model (Hestenes, 2006). In other words, a model is a customized and reduced presentation, setting forth typical characteristics of a system (Kurnaz, 2011). Mental models, on the other hand, are internal, cognitive presentations concerning reality (Bower \& Morrow, 1990; Rapp, 2005; Harrison \& Treagust, 1996). According to Nersessian (1992), mental models have predictive and explanatory features that give meaning to a targeted reality. It is important for a mental model to be functional (Greca and Moreira, 2000), In short, mental models are related to reality and are individual-specific, internal, incomplete, and dynamic simplifications.

Students' mental models concerning the system of reality can be established based on statements and actions (Hestenes, 2006; Kurnaz \& Değermenci, 2012). Understanding these mental models would provide important information for teachers and researchers about students' perceptions (Vosniadou, 1994) in terms of fulfilling expectations and increasing morale and motivation. The aim of this study is to determine mental models of pre-school students about school.

\section{Methods}

This research was a descriptive study conducted using survey research to describe a current situation as it is. A cross-sectional survey approach was used, requiring collecting data from various sampling groups over a certain period (Wiersma \& Jurs, 2005).

\section{Sample}

According to the data of the Department of National Education of Kastamonu (DNEK), a total of 1397 children aged 4-5 were receiving pre-school education in the city center of Kastamonu in the 2012-2013

(C) 2013, European Journal of Educational Research, 2(2), 97-105 
academic year, and the schooling rate is $41 \%$ (DNEK, 2011). Study participants included 334 kindergarten students (188 females, 146 males) in Kastamonu. The participants were selected by purposeful sampling method and constituted nearly one fourth of the population, which is important in terms of reliability of the findings.

\section{Data Collection Tool}

Since drawing reveals children's inner worlds, feelings, and desires (Coates, 2002; Einnarsdottir, Dockett, \& Perry, 2009; Leonard, 2006; Piperno, Di Biassi, \& Levi, 2007), the data were collected from pictures drawn by the children of the school of their dreams. Data collection with drawings has attracted attention as a very appropriate method for studies carried out with children (Kurnaz \& Değirmenci, 2012; Y1ld1z, 2012). During the 30 minute activity, students were asked to explain what they were drawing for the purpose of interpreting their depictions more accurately. During this process, the data were gathered by their own teacher as a lesson activity, and the researchers did not interfere the process.

\section{Analysis of Data}

Data analysis was performed in three stages. In the first stage, the figures in the paintings and the students' accompanying explanations were examined and scored based on a rubric structured around the literature (see Table 1). Each item in the rubric was worth a single point.

Table 1. Painting Analysis Rubric

\begin{tabular}{ll}
\hline Item & Content \\
\hline $\begin{array}{l}\text { School should be a place where children are entertained (Rieh et al., 2011; } \\
\text { Aksoy \& Baran, 2010) }\end{array}$ & Game/ \\
$\begin{array}{l}\text { School should have ecological features (Gür \& Zorlu, 2002; Owens \& } \\
\text { Valesky, as cited in Gislason, 2009) }\end{array}$ & Ecology \\
$\begin{array}{l}\text { School should be in a place where children can go by foot (Hine, 2009; } \\
\text { Uysal, 2006; Larouche et al., 2011). }\end{array}$ & Transportation \\
Schools should be a single-story (Gür \& Zorlu, 2002) & Structure \\
\hline
\end{tabular}

Scorings were the result of three researchers' assessments. Children were further classified into two categories: those who drew a school in harmony with the literature ( 3 or 4 total points) and those who didn't $(0,1$ or 2 total points). Although children included different elements in their paintings, certain elements were drawn more prominently in terms of their density, size etc. Highlighted elements were coded as themes across the paintings, and these themes were analyzed by the same three researchers in the second stage of analysis. In the third stage, the children's mental models of school were defined by comparing the findings set forth in the first two stages. More clearly, the conformity of the elements in the paintings with the scientific literature and the mental models with reference to the featured themes were determined. Some researches that define mental models with reference to the characteristics of students' answers (Harrison \& Treagust, 1996; Borges \& Gilbert, 1999; Lin \& Chiu, 2010) support the used method. 


\section{Findings}

The elements included in the paintings of children concerning the schools of their dreams were scored according to the rubric defined in Table 1. Score distribution of rubric items is shown in Table 2.

Table 2. Point Distribution of Children on Rubric Items

\begin{tabular}{|c|c|c|c|c|c|c|c|c|c|c|c|c|}
\hline \multirow{3}{*}{$\begin{array}{l}\text { Content of } \\
\text { Item }\end{array}$} & \multicolumn{4}{|c|}{ Girls } & \multicolumn{4}{|c|}{ Boys } & \multicolumn{4}{|c|}{ Total } \\
\hline & \multicolumn{2}{|c|}{1 point } & \multicolumn{2}{|c|}{0 point } & \multicolumn{2}{|c|}{1 point } & \multicolumn{2}{|c|}{0 point } & \multicolumn{2}{|c|}{1 point } & \multicolumn{2}{|c|}{0 point } \\
\hline & (f) & $\%$ & (f) & $\%$ & (f) & $\%$ & (f) & $\%$ & (f) & $\%$ & (f) & $\%$ \\
\hline Transportation & 183 & 93.3 & 5 & 6.7 & 129 & 88.4 & 17 & 21.7 & 312 & 93.4 & 22 & 6.6 \\
\hline Structure & 133 & 70.7 & 55 & 29.3 & 96 & 65.8 & 50 & 34.3 & 229 & 68.6 & 105 & 31.4 \\
\hline Ecology & 103 & 57.8 & 85 & 42.2 & 70 & 47.9 & 76 & 52.1 & 173 & 51.8 & 161 & 48.2 \\
\hline $\begin{array}{l}\text { Game/ } \\
\text { Entertainment }\end{array}$ & 7 & 3.7 & 181 & 96.3 & 6 & 4.1 & 140 & 96 & 13 & 3.9 & 321 & 96.1 \\
\hline
\end{tabular}

Almost none of the children included elements indicating that they would arrive at school by vehicle/school bus. More than half of the children drew a single-story school, and almost half drew a school closely associated with environmental elements. Almost none included elements related to entertainment. In addition, no significant difference was found between the points of females and males. Distribution of the points is shown in Table 3.

Table 3. Distribution of Children's Total Points

\begin{tabular}{lllllll}
\hline \multirow{2}{*}{ Point } & Girls & \multicolumn{3}{c}{ Boys } & Total \\
\cline { 2 - 7 } & $\mathrm{f}$ & $\%$ & $\mathrm{f}$ & $\%$ & $\mathrm{f}$ & $\%$ \\
\hline 0 & 2 & 1.07 & 1 & 0.68 & 3 & 0.90 \\
1 & 34 & 18.08 & 43 & 29.46 & 77 & 23.05 \\
2 & 70 & 37.23 & 51 & 34.93 & 121 & 36.23 \\
3 & 77 & 40.96 & 49 & 33.56 & 126 & 37.72 \\
4 & 5 & 2.66 & 2 & 1.37 & 7 & 2.1 \\
\hline
\end{tabular}

As seen in Table 3, the most frequently awarded points were 2 or 3 . No significant difference was found between female and male children in this distribution. A total of 133 children drew a school parallel to the literature ( 3 or 4 points), and 201 children did not ( 0,1 or 2 points). Distinguished themes in children's paintings are shown in Table 4.

Four themes were established concerning the paintings: complex building, ecological environment, game/entertainment, and transportation. The most emphasized theme was complex building. Once more, no significant difference was found between the female and male children. Figure 1 demonstrates sample images concerning the themes. 
Table 4. Distinguished Themes in Paintings

\begin{tabular}{lllllll}
\hline \multirow{2}{*}{ Themes } & \multicolumn{2}{c}{ Girls $(\mathrm{f})$} & \multicolumn{3}{c}{ Boys (f) } & \multicolumn{3}{c}{ Total } \\
\cline { 2 - 7 } & $\mathrm{f}$ & $\%$ & $\mathrm{f}$ & $\%$ & $\mathrm{f}$ & $\%$ \\
\hline Complex Structure & 108 & 57.45 & 90 & 61.64 & 198 & 59.28 \\
Ecology & 40 & 21.27 & 19 & 13.02 & 59 & 17.66 \\
Game/Entertainment & 37 & 19.68 & 21 & 14.38 & 58 & 17.37 \\
Transportation & 3 & 1.6 & 16 & 10.96 & 19 & 5.69 \\
\hline
\end{tabular}
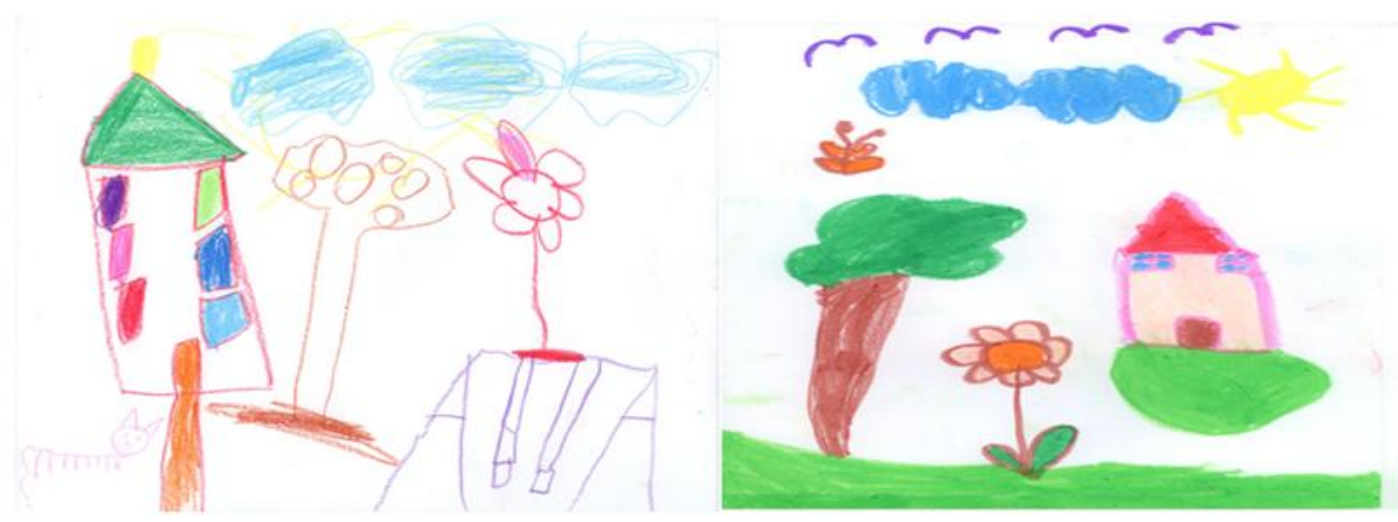

An example of entertainment/game oriented picture An example of ecology-oriented mental structure picture
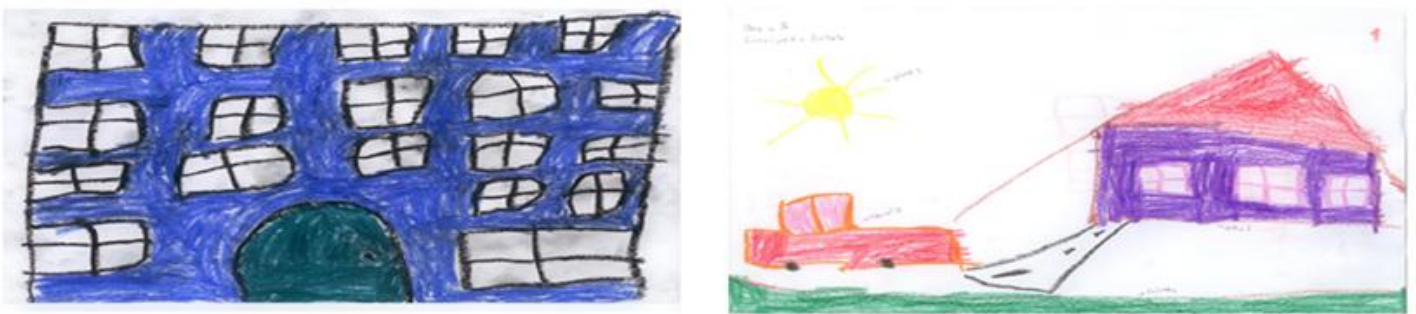

An example of complex (multi-story) school-oriented picture An example of transportation-oriented picture

Figure 1. Examples of pictures drawn by children.

Mental models were determined after considering the conformity of the elements in the paintings to the literature; distinguished themes are shown in Table 5.

tific:

Seven types of mental models were determined under the categories of scientific and nonscien-

Type 1: Science-based and entertainment/game-oriented mental structure;

Type 2: Science-based and natural environment-oriented mental structure;

Type 3: Science-based and complex (multi-story) school-oriented mental structure;

Type 4: Non-science-based and entertainment /game-oriented mental structure;

Type 5: Non-science-based and ecology-oriented mental structure;

Type 6: Non-science-based and classical school-oriented mental structure; and

Type 7: Non-science-based and transportation-oriented mental structure. 
As seen in Table 5, 40\% of the children had scientific-based (types 1, 2, and 3) mental models; $60 \%$ had nonscientific-based (types $4,5,6$, and 7 ) mental models. Children mostly demonstrated a type 5 model, and again, there was no significant difference between female and male children in terms of distribution.

Table 5. Mental Models of Children about School

\begin{tabular}{|c|c|c|c|c|c|c|c|c|c|}
\hline \multirow{2}{*}{ Mental Model } & & \multicolumn{2}{|c|}{ Girls } & \multicolumn{2}{|c|}{ Boys } & \multicolumn{4}{|c|}{ Total } \\
\hline & & (f) & $\%$ & (f) & $\%$ & $\mathrm{f}$ & $\%$ & $f$ & $\%$ \\
\hline \multirow{3}{*}{ Scientific } & Type 1 & 17 & 9,04 & 11 & 7,53 & 28 & 8,38 & \multirow{3}{*}{133} & \multirow{3}{*}{40} \\
\hline & Type 2 & 29 & 15,43 & 14 & 9,59 & 43 & 12,87 & & \\
\hline & Type 3 & 36 & 19,15 & 26 & 17,81 & 62 & 18,56 & & \\
\hline \multirow{4}{*}{ Non-scientific } & Type 4 & 20 & 10,64 & 10 & 6,85 & 30 & 8,98 & \multirow{4}{*}{201} & \multirow{4}{*}{60} \\
\hline & Type 5 & 70 & 37,23 & 64 & 43,84 & 134 & 40,12 & & \\
\hline & Type 6 & 12 & 6,38 & 5 & 3,42 & 17 & 5,09 & & \\
\hline & Type 7 & 4 & 2,13 & 16 & 10,96 & 20 & 5,99 & & \\
\hline
\end{tabular}

\section{Discussion and Conclusion}

The aim of this study was to determine mental models of schools for pre-school children. The findings characterized the research group and were limited to the paintings and rubric of the study. Discussions are tied to the descriptive findings and mental models.

\section{Descriptive Findings}

Almost none of the children included elements in their paintings indicating that school transportation should be a motor vehicle. This situation can be expressed as the effect of the children's daily life on their perceptions. Since the address-based school enrollment system began in Turkey, children are enrolled in the schools nearest to their homes. Thus, children were not permitted to go via motor vehicle, providing advantages for children's health (Hine, 2009), ensuring environmental consciousness (Uysal, 2006), and developing cognitive skills. In addition to these benefits, the savings on school transportation for the national economy cannot be ignored (Hine, 2009). More than half of the children drew a single-story school, and almost half of them drew a school closely associated with environmental elements. This finding received special attention from the researchers. Although Miller (2007) and Zoldosova and Prokop (2006) asserted that school buildings and the current educational system alienate children from their environment, this problem can be resolved by means of proper planning. In this regard, Owens and Valesky (as cited in Gislason, 2009) attached importance to ecological structure in their school architecture model.

In Turkey, kindergartens are generally two-stories, but they do not have sustainable architecture, big gardens, or ecological environments. Nevertheless, the expectations of the children were revealed through their pictures of single-story schools closely related to the environment. The research of Alerby (2000), Fleer (2002), and Özsoy (2012) determined that the attitudes of children concerning the environment becomes more negative as they grow. Some children in this study still had the perception of school as having a natural environment, so attitudes of children concerning the environment can still be salvaged and improved.

Further, the children did not present the school as a place for play or entertainment in their paintings, despite the fact that children aged 4-5 should be playing in developmental terms; their aim is 
to play in general (Berk, 2009). For example, Korean children expect schools to be fun places (Rieh et al., 2011). The children in this study may not see school as a place for games due to cultural values, such as a lack of concept that school can be a place where learning is fun.

\section{Mental Models}

Mental models of the children concerning school were categorized as scientific-based and nonscientific-based. Type 3 was the most common mental model within the scientific-based models. Children with this type perceived the school according to a scientific structure. However, the distinguished/dominant feature in their perception was that they considered the school, at the same time, as a complex building. Most kindergartens in Turkey are multi-story or located in the same campus with multi-story elementary schools, which may have affected the formation of this mental model. Although multi-story school buildings are common in Turkey, Turkish academicians, especially after the 1960s, asserted that single-story school buildings form healthier physical structures due to hygienic and pedagogic reasons (Gür and Zorlu, 2002). The system structure of schools is supported by the good format principle determined by Gestalt psychologists to make children comfortable. In multi-story buildings, the cognition of the children concerning school is completed until the final academic year. This situation harms the child's sense of feeling safe (Gür, 1993a, 1993b).

Type 5 was the most common mental model within the nonscientific-based models. The children who drew this model do not perceive schools as scientists design them. The distinguished/dominant feature in these pictures was a natural environment. Although this perception was scientific, other perceptions (building, game/entertainment, transportation) were not.

Architecture of educational fields is an area of expertise and requires collaboration across many disciplines (Woolner, 2011). Escolano (2003) and Kildan (2012) grouped the design of educational fields into either institutional or pedagogic architecture. While institutional architecture represents physical areas and outer spaces, inner spaces where educational activities are conducted fall under pedagogic architecture. Types 3 and 5 mental models in this study are closely related to institutional architecture. Thus, it can be suggested that further studies should be conducted to establish mental models of children concerning pedagogic architecture.

\section{References}

Aksoy, P., \& Baran, G. (2010). 60-72 aylık çocukların okula ilişkin algılarının resim yoluyla incelenmesi [Analysis of perceptions of 60-72 months children regarding school]. Paper presented at the International Conference on New Trends in Education and Their Implication, Antalya, Turkey.

Alerby, E. (2000). A way of visualizing children's and young people's thoughts about the environment: A study of drawings. Environmental Education Research, 6(3), 206-222.

Berk, L.E. (2009). Child development (8th ed.). Boston: Pearson.

Borges, A. T., \& Gilbert, J. K. (1999). Mental models of electricity. International Journal of Science Education, 21(1), 95-117.

Bower, G. H., \& Morrow, D. G. (1990). Mental models in narrative comprehension. Science, 247, 4448.

Brown, J. (2012). Citizens fit for the 21st century? The role of school design in facilitating citizenship and self-governance in young people. Education, Citizenship, and Social Justice, 7(1), 19-31.

Coates, E. (2002). 'I forgot the sky': Children's stories contained within their drawings. International Journal of Early Years Education, 10(1), 21-35. 
DNEK. (2011). Kastamonu İli Eğitim İstatistikleri [Education Statistics of Kastamonu], retrieved from http://kastamonu.meb.gov.tr/.

Durán-Narucki, V. (2008). School building condition, school attendance, and academic achievement in New York city public schools: A mediation model. Journal of Environmental Psychology, 28, 278-286.

Durkheim, E. (1972). Selected Writings. Cambridge: Cambridge University Press.

Einarsdottir, J., Dockett, S., \& Perry, B. (2009). Making meaning: Children's perspectives expressed through drawings. Early Child Development and Care, 179(2), 217-232.

Escolano, A. (2003). The school in the city: School architecture as discourse and as text. Paedagogica Historica, 39(1), 53-64.

Fleer, M. (2002). Curriculum compartmentalization?: A futures perspective on environmental education. Environmental Education Research, 8(2), 137-154.

Gislason, N. (2009). Mapping school design: A qualitative study of the relations among facilities design, curriculum delivery, and school climate. Journal of Environmental Education, 40(4), 17-33.

Gislason, N. (2010). Architectural design and the learning environment: A framework for school design research. Learning Environments Research, 13(2), 127-145.

Greca, I. M., \& Moreira, M. A. (2000). Mental models, conceptual models, and modeling. International Journal of Science Education, 22(1), 1-11.

Green, D., \& Turrell, P. (2004). School building investment and impact on pupil performance. Facilities, 23(5/6), 253-261.

Gür, Ş. Ö. (1993a). İlkokul öğrencilerinin okul çevrelerini bilişsel olarak değerlendirmelerinin tasarımdaki yorumu [Elementary school students' assessments of cognitive design review environment design review]. Paper presented at the III. Yap1/Yaşam Uluslar arası Kongresi, Bursa.

Gür, Ş. Ö. (1993b). Çocukların planlama ve tasarlama kararlarına katılımı [Children's participation in planning and design decisions]. Paper presented at the 21.yy Doğru Eğitim Yapıları Sempozyumu, İstanbul.

Gür, Ş. Ö., \& Zorlu, T. (2002). Çocuk mekanları [Child venues]. İstanbul: Yapı-endüstri merkezi yayınları.

Harrison, A. G., \& Treagust, D. F. (1996). Secondary students' mental models of atoms and molecules: Implications for teaching chemistry. Science Education, 80(5), 509-534.

Hestenes, D. (2006). Notes for a modeling theory of science, cognition and instruction. In E. van den Berg, T. Ellermeijer, \& O. Slooten (Eds.), Proceedings GIREP Conference 2006: Modelling in Physics and Physics Education, 34-65.

Hine, J. (2009). The provision of home to school transport in Northern Ireland. Research in Transportation Economics, 25, 29-38.

Hoy, W. K., \& Miskel, C. G. (2005). Educational administration: Theory, research and practice (7th ed.). Boston: McGraw-Hill.

Kastamonu Milli Eğitim Müdürlüğü. (2011). Sayısal veriler. Kastamonu: Milli Eğitim Yayınları.

Kildan, A.O. (2012). A study on developing a quality scale for preschool education institutions based on parents' views. Energy Education Science and Technology, Part B, 4(4), 2377-2382.

Kumar, R., O'Malley, P. M., \& Johnston, L. D. (2008). Association between physical environment of secondary schools and student problem behavior. Environment and Behavior, 40(4), 455-486.

Kurnaz, M. A. (2011). Enerji konusunda model tabanli öğrenme yaklaşimina göre tasarlanan öğrenme ortamlarinin zihinsel model gelişimine etkisi [The effect of learning environments based on model-based learning approach to mental model development about energy subject]. Unpublished doctoral dissertation, Karadeniz Teknik Üniversity, Trabzon, Türkiye. 
Kurnaz, M. A., \& Değermenci, A. (2012). Mental models of 7th grade students on sun, Earth and moon. Elementary Education Online, 11(1), 137-150.

Larouche, R., Lloyd, M., Knight, E., \& Tremblay, M. S. (2011). Relationship between active school transport and body mass index in grades 4 to 6 children. Pediatric Exercise Science, 23, 322-330.

Leiringer, R., \& Cardellino, P. (2011). Schools for the twenty-first century: School design and educational transformation. British Educational Research Journal, 37(6), 915-934.

Leonard, M. (2006). Children's drawings as a methodological tool: reflections on the develop plus system in Northern Ireland. Irish Journal of Sociology, 15(2), 52-66.

Lin, J. W., \& Chiu, M. H. (2010). The mismatch between students' mental models of acids/bases and their sources and their teacher's anticipations thereof. International Journal of Science Education, 32(12), 1617-1646.

Miller, D. L. (2007). The seeds of learning: Young children develop important skills through their gardening activities at a midwestern early education program. Applied Environmental Education and Communication, 6(1), 49-66.

Nersessian, N. J. (1992). How do scientists think? Capturing the dynamics of conceptual change in science. In R. N. Giere (Ed.), Cognitive models of science (pp. 3-44). Minneapolis, MN: University of Minnesota Press.

Özsoy, S. (2012). Investigating elementary school students' perceptions about environment through their drawings. Educational Sciences: Theory and Practice, 12(2), 1117-1139.

Piperno, F., Di Biassi, S., \& Levi, G. (2007). Evaluation of family drawings of physically and sexually abused children. European Child \& Adolescent Psychiatry, 16(6), 389-397.

Rapp, D. (2005). Mental models: Theoretical issues for visualizations in science education. In J. Gilbert (Ed.), Visualization in science education (pp. 43-60). Netherlands: Springer.

Rieh, S. Y., Kim, J. K., \& Yu, W. S. (2011). User participation: A new approach to school design in Korea. CELE Exchange, No. 2011/4.

Saban, A. (2008). Metaphors about school. Educational Administration: Theory and Practice, 55, 459496.

Tanner, C. K. (2000). The influence of school architecture on academic achievement. Journal of Educational Administration, 38(4), 309-330.

Uysal, F. (2006). A study on indoor and outdoor space organizations at preschool education centers, regarding the education theories (Unpublished master's thesis). Gazi University Institute of Natural Sciences, Ankara, Turkey.

Vosniadou, S. (1994). Capturing and modeling the process of conceptual change. Learning and Instruction, 4, 45-69.

Weber, M. (1964). The theory of social and economic organization. (A. M. Henderson and T. Parsons, Trans.). New York: The Free Press.

Wiersma, W., \& Jurs, S. G. (2005). Research methods in education (8th ed.). Boston: Allyn and Bacon.

Wong, B. Y., Faulkner, G., Buliung, R., \& Irving, H. (2011). Mode shifting in school travel mode: Examining the prevalence and correlates of active school transport in Ontario, Canada. BMC Public Health, 11, 618.

Woolner, P. (2011). Creating individualized optimal learning environments through participatory design. Educational and Child Psychology, 28(1), 9-19.

Yildiz, S. A. (2012). A qualitative analysis of school concept on primary school students. Educational Sciences: Theory and Practice, 12(2), 626-626.

Zoldsova, K., \& Prokop, P. (2006). Education in the field influences children's ideas and interest toward science. Journal of Science Education and Technology, 15(3), 304-313. 